\title{
The survey of drinking water supply in Estonia from the point of view of public health
}

\author{
E. Indermitte ${ }^{1,2}$, A. Saava ${ }^{1} \&$ A. Kull ${ }^{2}$ \\ ${ }^{I}$ Department of Public Health, University of Tartu, Estonia \\ ${ }^{2}$ Institute of Geography, University of Tartu, Estonia
}

\begin{abstract}
Access to a sufficient supply of safe drinking water is essential in maintaining public health. The quality of water and associated health risks vary throughout the world with some regions showing contamination of drinking water by pathogens or high levels of chemical compounds, whereas elsewhere these are very low and present no problem for human health. Considerable variations also occur on a more local level within countries. The purpose of the study was to analyse the status of public water supply and drinking water quality in towns and rural settlements of Estonia and its possible impact on public health. The basis of the study was the Health Protection Inspectorate database on the water suppliers and water quality. A special study was carried out to determine fluoride content (the main toxic chemical of concern in Estonia) in drinking water. All towns and rural settlements with water supply systems serving at least 100 inhabitants were visited and water samples were taken. The access to public drinking water supplies by counties was analysed. The exposure of the population to selected chemicals of concern was determined. Estonia is characterised by a large proportion of small water supplies. It makes the safeguarding of water quality and control complicated. The percentage of the population exposed to toxic compounds (fluoride, boron) was small and this occurred mainly in the case of small water supplies. At the same time a considerable amount of the population is influenced by undesirable chemicals (iron, manganese, etc.). These substances are non-toxic but disturb the conditions of water usage and quality of life. The priority in planning and improving public water supply should be given to activities minimising the health risks from toxic components in drinking water. Keywords: drinking water supply, health risks, Estonia, fluoride.
\end{abstract}




\section{Introduction}

Serving the population with adequate drinking water is an important prerequisite for a healthy life. Inadequate access to clean drinking water directly and indirectly affects health. Adverse health outcomes are associated with ingestion of and contact with unsafe water as well as with lack of access to water (linked to inadequate hygiene) [1]. The contamination of drinking water by pathogens causing diarrhoeal disease is the most important aspect of drinking water quality. During 1986-1996, 710 outbreaks of waterborne diseases with 52000 cases were reported in 19 European countries [2].

There are many sources of chemical contaminants in drinking water. Many environmental contaminants in drinking water have clear evidence of adverse effects on human health. The most important contaminants from a standpoint of health are naturally occurring environmental contaminants (arsenic, fluoride, selenium, boron) in drinking water. At high exposures, these chemicals can cause serious toxic effects or chronic diseases in humans [3].

Waterborne diseases not only cause preventable illness and death but may also have substantial economic effects on the affected people and their families and society as a whole, including expenses for healthcare and loss of productivity.

The quality of drinking water and possible associated health risks vary throughout the world with some regions showing, for example, high levels of toxic chemicals or contamination of drinking water by pathogens, whereas elsewhere these are very low and present no problem for human health. Similar problems may occur within countries [4]. Differences in health risks that local level variations represent lead to different priorities for the provision and treatment of drinking water. To be able to set priorities, good survey on access to water supply and quality data on the levels of contaminants in water and related health risks are needed. The purpose of current survey was to analyse the status of public water supply and drinking water quality in towns and settlements of Estonia and its possible impact on public health.

\section{Materials and methods}

\subsection{Study area}

Estonia is the smallest and the northenmost Baltic country with an area of $45227 \mathrm{~km}^{2}$ and population of 1,35 million people (01.01.2004). Administratively Estonia is divided into 15 counties. Located in northern Europe, geologically Estonia is situated in the north-western part of the EastEuropean Platform. Surface water in two big towns (capital Tallinn and Narva) and deep groundwater from drilled tube wells in other towns and rural settlements are the main sources of drinking water. Groundwater sources rely on five aquifer systems (Middle-Devonian, Middle-Lower-Devonian, SilurianOrdovician, Ordovician-Cambrian and Cambrian-Vendian) which differ from 
each other in distribution and chemical composition [5]. In addition, groundwater from shallow dug wells in suburbs and rural areas are used.

\subsection{Data}

A survey of public water supplies was performed all over Estonia. Data on access of population to public water supplies and water quality was obtained from Estonian Health Protection Inspectorate database on drinking water "JVESI". Public water supplies were categorised into 5 groups according to their size (number of consumers served): <500; 500-1999; 2000-9999; 10 000-49 000; $\geq 50000$ inhabitants. Drinking water quality was analysed from three aspects of public health: microbiological safety; chemicals affecting water properties and quality of life (iron, manganese, chlorides, sulphates and nitrites); and toxic chemicals causing direct health effects (fluorides, boron, nitrates). Data was grouped into two categories according to the Estonian drinking water requirements [6]: parameter level not exceeding the threshold value; and parameter consistently exceeding the threshold value. Depending on parameter the data were available for 1062-1074 public water supplies.

The exposure of population to selected chemicals of concern was determined by linking the parameter level in water to the number of consumers in corresponding water supply system.

\subsection{Special study}

A special study to determine fluoride content in drinking water was carried out in 2004. Fluoride has a special public health interest because of its anti-caries effect at low concentration, but excessive levels may cause serious adverse effects including dental and skeletal fluorosis, bone fractures and other diseases [7-9]. All towns and rural settlements with public water supplies serving at least 100 inhabitants were visited and water samples were taken. SPADNS colorimetric method was used to determine fluoride concentration [10]. This method is accepted by WHO for field studies [3]. Standard reference solutions were analyzed before and after mesurements, the relative error during measurements was $2,0 \%$. Altogether 735 water samples were collected in 47 towns and 471 rural settlements in all 15 counties throughout Estonia. Data was grouped into 3 categories according to their health effects:

1) high-fluoride content drinking water (over $1,50 \mathrm{mg} / \mathrm{l}$ ) - causing adverse health effects;

2) 2) optimal fluoride content drinking water $(0,51-1,50 \mathrm{mg} / \mathrm{l})$ - having protection against dental caries with the least risk of producing dental fluorosis or other toxic effects;

3) low-fluoride content drinking water (up to $0,50 \mathrm{mg} / \mathrm{l}$ ) - insufficient to prevent caries.

For data processing and analysing a statistical package SPSS 10.0 for Windows was used. 


\section{Results}

\subsection{Access of population to public water supplies (PWS)}

Population of Estonia is well provided with drinking water $-82,9 \%$ rely on public water supply facilities. Access to drinking water among urban population is $95,6 \%$ and among rural population $55,9 \%$. There are altogether 1233 PWS. The large proportion of PWS is small by size (Figure 1). Up to $86,1 \%$ of PWS serve less than 500 inhabitants. It makes the safeguarding of water quality and control complicated. Up to $21,9 \%$ of PWS are so small ( $<50$ consumers) that they are exempted from water quality and control requirements [5]. Only 3 PWS $(0,2 \%)$ have each over 50000 consumers. Altogether they serve $41,1 \%$ of population.

The access to PWS differs by counties as well as by towns and rural settlements. The population in more industrialised regions (Harju and Ida-Viru counties) has significantly higher access to PWS in comparison with population in marginal borderland Võru and Põlva counties (over 90\% and about $60 \%$, respectively). Among towns the access to PWS ranges from 35 to $100 \%$ (average $83 \%$ ), at the same time in some rural settlements the access was even less than $20 \%$. Dispersed rural families depend almost entirely on groundwater from private wells for their potable water supply.

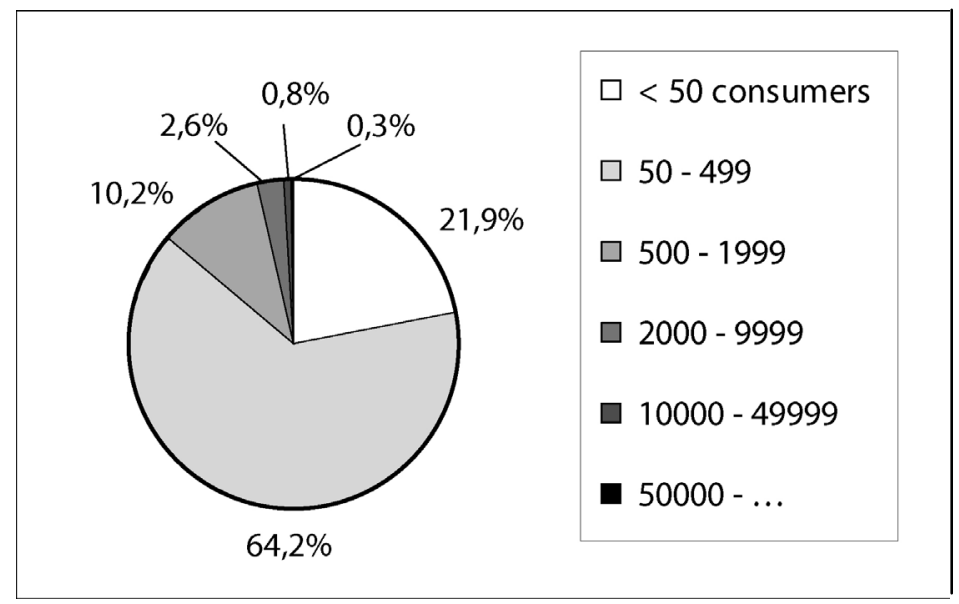

Figure 1: Distribution of water supplies by the number of consumers.

\subsection{Drinking water quality}

\subsubsection{Microbiological quality of water}

The parameters analysed were: content of Escherichia coli (E. coli), Enterococci, total coliforms and colony count at $22^{\circ} \mathrm{C}$. The number of studied PWS ranged from 1072 to 1074 depending on parameter. 
Drinking water did not satisfy the requirements for microbiological parameters in 13 PWS (1,2\%). All four analysed parameters were exceeded in one PWS (rural settlement Roosna-Alliku with 155 consumers), two parameters (E. coli and Enterococci) - in 5 PWS, only one parameter - in 6 PWS. All these PWS were small ( $<300$ consumers).

\subsubsection{Chemical quality of water}

Among chemicals deteriorating organoleptic properties of water and affecting quality of life iron exceeded the limit value most frequently. In total $495(46,6 \%)$ PWS had constant high levels of iron. The highest number of PWS exceeding the limit was in Harju followed by Ida-Viru, Viljandi and Lääne-Viru counties (Table 1). The threshold value for manganese was exceeded in 136 and for chlorides in 30 PWS. Most of PWS exceeding the limit for manganese also had high iron content. Poor water quality was detected mostly in small PWS serving rural settlements and borough-towns. Content of sulphates and nitrites in water satisfied the requirements in all PWS.

Table 1: $\quad$ Number of PWS exceeding the limit for iron by settlement type.

\begin{tabular}{lrcccc}
\hline County & No of & \multicolumn{4}{c}{ No of PWS exceeding the limit value } \\
\cline { 3 - 6 } & PWS & Towns & $\begin{array}{c}\text { Borough- } \\
\text { towns }\end{array}$ & $\begin{array}{c}\text { Rural } \\
\text { settlements }\end{array}$ & Total \\
\hline Harju & 129 & 11 & 26 & 39 & 76 \\
Hiiu & 22 & & & 11 & 11 \\
Ida-Viru & 78 & 14 & 14 & 35 & 63 \\
Jõgeva & 54 & 1 & 10 & 12 & 23 \\
Järva & 77 & 1 & 7 & 20 & 28 \\
Lääne & 32 & 3 & 1 & 9 & 13 \\
Lääne-Viru & 109 & 5 & 12 & 34 & 51 \\
Põlva & 73 & 1 & 4 & 12 & 17 \\
Pärnu & 60 & 2 & 16 & 23 & 41 \\
Rapla & 73 & 2 & 16 & 16 & 34 \\
Saare & 57 & & 2 & 10 & 12 \\
Tartu & 91 & 2 & 15 & 32 & 49 \\
Valga & 66 & 2 & 3 & 11 & 16 \\
Viljandi & 80 & 5 & 7 & 40 & 52 \\
Võru & 61 & & 4 & 5 & 9 \\
\hline Total & 1062 & 49 & 137 & 309 & 495
\end{tabular}

Among toxic chemicals only fluoride and boron exceeded permissible level: fluoride in 102 and boron in 21 PWS. There was a correlation $(r=0,80)$ between fluoride and boron content in drinking water. Level of nitrates was in compliance with drinking water requirements in all PWS. Table 2 presents the exposure of population to drinking water not satisfying the quality requirements by the settlement type. 
Table 2: $\quad$ Exposure of population exposure to chemicals exceeding threshold values.

\begin{tabular}{lrrrrr}
\hline Parameter & No of & \multicolumn{4}{c}{ Exposed population } \\
\cline { 3 - 6 } & PWS & Total & Towns & $\begin{array}{c}\text { Borough- } \\
\text { towns }\end{array}$ & $\begin{array}{c}\text { Rural } \\
\text { settlements }\end{array}$ \\
\hline Iron & 495 & 411116 & 306003 & 60620 & 44493 \\
Manganese & 136 & 110028 & 73790 & 25963 & 10275 \\
Chlorides & 30 & 60350 & 52093 & 6935 & 1322 \\
Fluorides & 102 & 42571 & 8115 & 19037 & 15419 \\
Boron & 21 & 8398 & 1530 & 3570 & 3298 \\
\hline
\end{tabular}

\subsubsection{Fluoride content in drinking water}

Fluoride content in drinking water varied in a large scale: 0,01-6,95 mg/l with a mean of $0,88 \mathrm{mg} / \mathrm{l}(\mathrm{SD} 0,90)$. In $306(41,6 \%)$ samples the fluoride content was below $0,5 \mathrm{mg} / \mathrm{l}$. Optimal concentration $(0,5-1,5 \mathrm{mg} / \mathrm{l})$ was measured in 323 $(44,0 \%)$ samples. The permissible limit - 1,5 mg/l - was exceeded in 106 $(14,4 \%)$ samples. Fluoride content varied greatly both between and within counties (Table 3 ).

Table 3: $\quad$ Fluoride concentration in water samples by counties.

\begin{tabular}{lccccc}
\hline \multirow{2}{*}{$\begin{array}{c}\text { Name of } \\
\text { county }\end{array}$} & Number of & \multicolumn{4}{c}{ Fluoride concentration, mg/l } \\
\cline { 3 - 6 } & samples & Min & Max & Mean & SD \\
\hline Harju & 119 & 0,01 & 2,06 & 0,72 & 0,39 \\
Hiiu & 17 & 0,38 & 1,92 & 1,12 & 0,44 \\
Ida-Viru & 48 & 0,21 & 1,29 & 0,59 & 0,24 \\
Jõgeva & 38 & 0,06 & 3,28 & 0,81 & 0,78 \\
Järva & 49 & 0,05 & 3,12 & 0,82 & 0,71 \\
Lääne & 29 & 0,54 & 5,60 & 2,25 & 1,46 \\
Lääne-Viru & 65 & 0,10 & 1,81 & 0,49 & 0,32 \\
Põlva & 31 & 0,08 & 1,10 & 0,34 & 0,27 \\
Pärnu & 63 & 0,08 & 6,95 & 1,84 & 1,53 \\
Rapla & 42 & 0,12 & 3,68 & 1,25 & 0,97 \\
Saare & 28 & 0,22 & 5,50 & 1,14 & 1,11 \\
Tartu & 73 & 0,10 & 3,48 & 0,82 & 0,65 \\
Valga & 30 & 0,06 & 1,58 & 0,35 & 0,31 \\
Viljandi & 56 & 0,05 & 2,56 & 1,02 & 0,70 \\
Võru & 47 & 0,08 & 0,45 & 0,26 & 0,10 \\
\hline Total & 735 & 0,01 & 6,95 & 0,88 & 0,90
\end{tabular}

Higher values as well as higher proportion of high-fluoride water samples were collected from Pärnu, Lääne and Rapla counties in West-Estonia. On the other hand, natural low-fluoride groundwater was prevalent in Võru, Valga and Põlva counties in South-Estonia (Figure 2). The low-fluoride drinking water was also prevalent in capital Tallinn and town Narva. Both towns use mostly surface water. The analysis of PWS providing high-fluoride water by number of consumers revealed that this type of water is mainly a problem in small water 
supplies. In majority $(77,4 \%)$ of cases each supply serves less than 500 inhabitants. Nevertheless, there are still $11(10,6 \%)$ supplies that serve each over 1000 inhabitants. The biggest of them has 4000 consumers (town Türi).

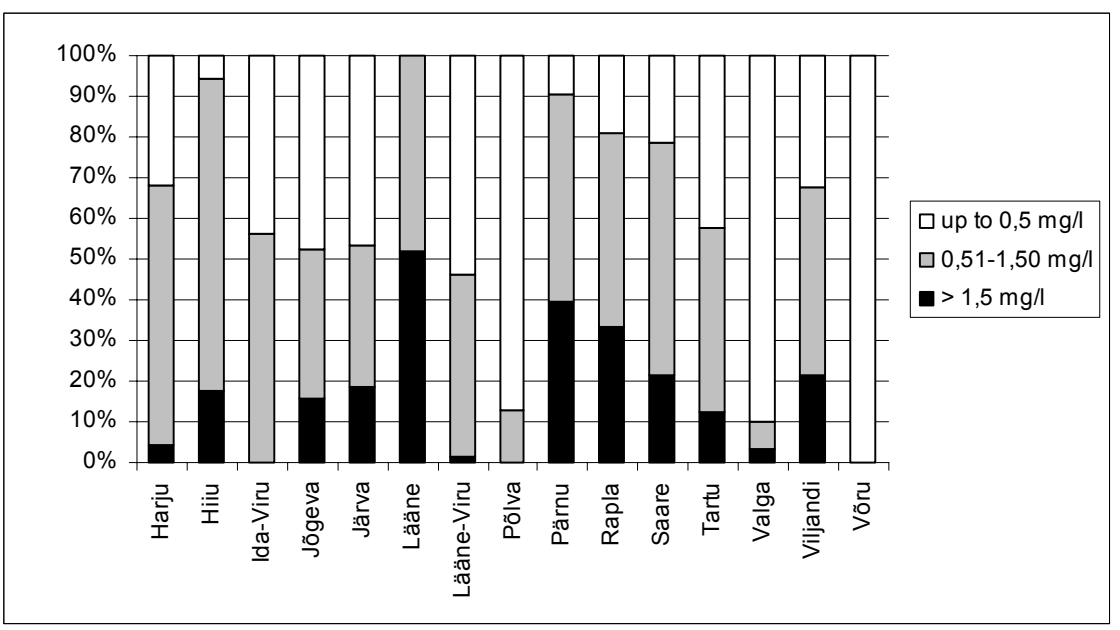

Figure 2: Distribution of fluoride levels in water samples by counties.

\section{Discussion}

Water is an essential factor in the maintenance of human health; poor availability and quality can have severe effects on the health of populations and their quality of life.

Population of Estonia is well provided with drinking water which is derived from surface sources in capital Tallinn (lake Ülemiste) and town Narva (river Narva) and from several groundwater aquifers in other places. Water contains natural contaminants, particularly inorganic chemicals that arise from the geological strata, through which the water flows, and a varying extent, anthropogenic pollution both by micro-organisms and chemicals. In general, groundwater is less vulnerable to pollution than surface waters.

Overall access of population to PWS is high $-82,9 \%$, but variations between geographical regions as well as between towns are significant. Access to PWS may be overestimated to certain extent due to decrease of population during last decade. Database on water suppliers was established in 2002. In settlements where schools or other establishments have separate water supply system there was possibility to consider the number of water consumers twice (at school and at home). Rural population has lower coverage of PWS than urban population $(55,9 \%$ and $95,6 \%$, respectively). This can be due to logistical difficulties, relative cost and political priorities.

The prevalence of small PWS is characteristic for Estonia. This complicates the improvement and control of water quality. No regulations of water quality and control exist for the PWS serving less than 50 consumers [6]. 
The quality of drinking water in PWS depends on many factors, including the quality of the raw water source, the extent and type of treatment and disinfection used, the materials and integrity of the distribution system, and maintenance of positive pressure within the network.

The water supply systems in many towns are obsolete. During recent years, drinking water supply has improved to great extent, especially where EU support has become available for modernising water supply systems and water treatment.

The provision of microbiologically safe drinking water supply is the most important step that can be taken to improve health of a community. The pathogenic organisms directly responsible for the spread of disease are of concern, but detecting them is difficult, expensive and time-consuming. Instead, water is examined for bacteria Escherichia coli and Enterococci that indicate the presence of faecal contamination. Total coliforms and colony count at $22^{\circ} \mathrm{C}$ serve as the indicators of general pollution of water.

The analysis of bacterial quality of drinking water showed that there is no significant risk from faecal contamination of water. No waterborne outbreaks have been occurred in Estonia during last decade. Occasional epidemiological hazard was identified in 7 PWS. In remaining cases (6 PWS) only indicators were detected. The contamination was caused by an inadequate supply process or by a lack of maintenance of distribution pipelines.

The bacterial quality of drinking water depends on a number of factors - the depth of the aquifer, the condition of the distribution network, the efficiency of treatment and disinfection in particular. Through improved monitoring and surveillance, increased understanding of distribution system deficiencies may focus limited resources on key areas in an effort to improve public health and decrease disease burden [11].

The problems associated with chemicals in drinking water arise from their ability to affect the organoleptic properties of water and quality of life (iron, manganese, chloride) or to cause adverse health effects after prolonged periods of exposure (fluorides, boron). In Estonia drinking water quality is acceptable for majority of the population which is served by the larger PWS. Iron is the most frequently occurring chemical exceeding the threshold value in drinking water, preferable in small PWS. Iron salts are unstable in drinking water supplies. They are precipitated as insoluble iron hydroxide, which causes colour and turbidity of water and settles out as rust-coloured silt. Iron also promotes undesirable bacterial growth in waterworks and distribution systems, resulting in the deposition of a slimy coating on the piping. The taste and appearance of water will usually be affected below the level, which can present a hazard to health. Iron removal technology is not complicated and expensive. Appropriate treatment equipment is already installed or planned to install by many PWS.

Fluorides exist naturally in groundwater. They enter groundwater systems through dissolution and leaching of mineral deposits and rock formations. The beneficial effect of fluoride in drinking water has a very narrow range. Low concentrations provide protection against dental caries (especially in children), but excessive intake of fluoride via drinking water may cause serious toxic effects [12]. Low fluoride drinking water is prevalent in southern Estonia (Võru, 
Valga and Põlva counties), where the major source of drinking water is terrogenous Middle-Devonian aquifer system. High fluoride content (over $1,5 \mathrm{mg} / \mathrm{l}$ ) was detected first of all in the West-Estonia (Lääne, Rapla and Pärnu counties), where the only drinking water source is Silurian-Ordovician aquifer system. Elevated fluoride content was also found in some PWS of central Estonia (Tartu and Järva counties) scooping water from Devonian-Silurian aquifer system. In these areas, there is no industry or any human activity that can cause anthropogenic contamination of fluoride into the groundwater. High levels of fluoride are due to geogenic source - natural Silurian and Ordovician rocks [13].

It is difficult and expensive to reduce a natural high level of fluoride in water. The first option should be to find an alternative source with lower fluoride level. Surface water would be preferable. Also, mixing water from different sources can lower the fluoride level in drinking water. If there is no other possibility or cost-effective solution, de-fluoridation must be attempted to avoid the toxic effects. The best method depends on local circumstances.

\section{Conclusions}

Population of Estonia is well provided with drinking water, but access to public water supply system varies significantly between towns and counties. Urban population has higher coverage than rural population.

The drinking water quality problems are associated with high levels of iron, manganese and fluoride naturally occurring in ground water. The obsolescence and bad technical conditions of water supply networks are an additional factor to contribute deterioration of drinking water quality. It is of a particular concern in small supplies.

In conjunction with building new and renovating existing housing complexes, a stepwise extension of public water supply systems and improvement of the hygienic conditions in urban and surrounding rural areas could be achieved. Protected source of water and modern, well-maintained drinking water treatment plants can provide water adequate for human consumption.

\section{Acknowledgements}

This study has been supported by the Target Funding Projects No. 0182143s02 and No. 0182648s04 of the Ministry of Education and Science, Estonia and by the Estonian Dental Association.

\section{References}

[1] EEA and WHO. Water and Health in Europe: a joint report from the European Environmental Agency and the WHO Regional Office for Europe. Ed. J. Bartram WHO Regional Publications. European series; No 93, 2000, $222 \mathrm{p}$. 
[2] WHO/EURO. Health and the environment in the WHO European Region: Situation and policy at the beginning of the $21^{\text {st }}$ century. Ed I.D. Ivanov. Fourth Ministerial Conference on Environment and Health, Budapest, Hungary, 23-25 June 2004, Geneva, 2004, 203 p.

[3] WHO. Guidelines for drinking-water quality. $3^{\text {nd }}$ edn, vol. 1 . Recommendations, World Health Organization, Geneva, 2004, 455 p.

[4] Karro, E., Rosentau, A. Fluoride levels in the Siluarian-Ordovician aquifer system of western Estonia. Fluoride 38(4), pp. 307-311, 2005.

[5] Karise, V., Metsur, M., Perens, R., Savitskaja, L., Tamm, I. Eesti põhjavee kasutamine ja kaitse [Use and protection of groundwater in Estonia]. Eesti Põhjaveekomisjon, Tallinn (in Estonian), 2004, 81 p.

[6] Ministry of Social Affairs, Estonia. Joogivee kvaliteedi- ja kontrollinõuded ning analüüsimeetodid [The quality and monitoring requirements for drinking water and methods of analysis]. SoM RTL 2001/100/1369, Tallinn (in Estonian), 2001.

[7] Moturi, W.K., Tole, M.P., Davies, T.C. The contribution of drinking water towards dental fluorosis: a case study of Njoro Division, Nakuru District, Kenya. Environ. Geochem. Health 24, pp. 123-130, 2002.

[8] Xiang, Q., Liang, Y., Chen, L., Wang, C., Chen, B., Chen, X., Zhou, M. Effect of fluoride in drinking water on children's intelligence. Fluoride 36(2), pp. 84-94, 2003.

[9] Alarcon-Herrera, M.T., Martin-Dominquez, I., Trejo-Vazquez, R., Rodriquez-Dozal, S. Well water fluoride, dental fluorosis, bone fractures in the Guadiana Valley of Mexico. Fluoride 34(2), pp. 139-149, 2001.

[10] APHA. Standard methods for the examination of water and wastewater, $2^{\text {nd }}$ edn. Washington, DC, American Public Health Association, 1998.

[11] Lee, E.J., Schwab, K.J. Deficiencies in drinking water distribution systems in developing countries. J Water Health 3(2), pp. 109-127, 2005.

[12] Connett, P. US National Research Council Subcommittee on fluoride in drinking water. Fluoride 36(4), pp. 280-289, 2003.

[13] Karro, E., Indermitte, E., Saava, A., Haamer, K., Marandi, A. Fluoride occurrence in publicly supplied water in Estonia. Environmental Geology, DOI 10.1007/s00254-006-0217-1 (in print), 2006. 